\title{
Omega-3 Fatty Acid Docosahexaenoic Acid Increases SorLA/ LR11, a Sorting Protein with Reduced Expression in Sporadic Alzheimer's Disease (AD): Relevance to AD Prevention
}

\author{
Qiu-Lan Ma, ${ }^{1,3}$ Bruce Teter, ${ }^{1,3}$ Oliver J. Ubeda, ${ }^{1,3}$ Takashi Morihara, ${ }^{1,3,4}$ Dilsher Dhoot, ${ }^{1,3}$ Michael D. Nyby, \\ Michael L. Tuck, ${ }^{1}$ Sally A. Frautschy, ${ }^{1,2,3}$ and Greg M. Cole ${ }^{1,2,3}$ \\ Departments of ${ }^{1}$ Medicine and ${ }^{2}$ Neurology, University of California, Los Angeles, California $90095,{ }^{3}$ Geriatric Research, Education and Clinical Center, \\ Veterans Affairs, Greater Los Angeles Healthcare System, North Hills, California 91343, and ${ }^{4}$ Department of Post-Genomics and Diseases, Division of \\ Psychiatry and Behavioral Proteomics, Osaka University Graduate School of Medicine D3, Suita-shi, Osaka 565-0871, Japan
}

Environmental and genetic factors, notably ApoE4, contribute to the etiology of late-onset Alzheimer's disease (LOAD). Reduced mRNA and protein for an apolipoprotein E (ApoE) receptor family member, SorLA (LR11) has been found in LOAD but not early-onset AD, suggesting that LR11 loss is not secondary to pathology. LR11 is a neuronal sorting protein that reduces amyloid precursor protein (APP) trafficking to secretases that generate $\beta$-amyloid $(\mathrm{A} \beta)$. Genetic polymorphisms that reduce LR11 expression are associated with increased AD risk. However these polymorphisms account for only a fraction of cases with LR11 deficits, suggesting involvement of environmental factors. Because lipoprotein receptors are typically lipid-regulated, we postulated that LR11 is regulated by docosahexaenoic acid (DHA), an essential $\omega-3$ fatty acid related to reduced AD risk and reduced $A \beta$ accumulation. In this study, we report that DHA significantly increases LR11 in multiple systems, including primary rat neurons, aged non-Tg mice and an aged DHA-depleted APPsw AD mouse model. DHA also increased LR11 in a human neuronal line. In vivo elevation of LR11 was also observed with dietary fish oil in young rats with insulin resistance, a model for type II diabetes, another AD risk factor. These data argue that DHA induction of LR11 does not require DHA-depleting diets and is not age dependent. Because reduced LR11 is known to increase A $\beta$ production and may be a significant genetic cause of LOAD, our results indicate that DHA increases in SorLA/LR11 levels may play an important role in preventing LOAD.

Key words: SorLA; LR11; Alzheimer; docosahexaenoic acid; diet; omega-3 fatty acid; amyloid

\section{Introduction}

Abnormal accumulation of $\beta$-amyloid $(A \beta)$ is an early event in Alzheimer's disease (AD) pathogenesis. Consistent with this, in $\sim 5 \%$ of $\mathrm{AD}$ patients, mutations increasing $\mathrm{A} \beta 1-42$ production can cause early-onset familial AD (FAD) ( $<65$ years) (Goate et al., 1991; Rogaev et al., 1995; Sherrington et al., 1995). Late-onset ( $>65$ years) sporadic AD (LOAD) is less clearly caused by a single mutation but influenced by some combination of genetic and environmental risk factors, notably Apolipoprotein E4 (ApoE4) (Saunders et al., 1993; Bales et al., 1997). Later onset is associated with less genetic influence and more environmental modification of risk. Consistent with this, in LOAD, high discordance rates or large delays in onset occur in monozygotic twins, demonstrating the significance of environmental factors (Pedersen et al., 2004).

Recently, the neuronal sortilin-related receptor SorLA/LR11

Received Aug. 8, 2007; revised 0ct. 10, 2007; accepted 0ct. 30, 2007.

This work was supported by National Center for Complementary and Alternative Medicine Grant AT3008 and initiated with support from National Institute of Aging Grant AG13471. We thank Drs. Fusheng Yang and Pirooz Eslami, Walter Beech, Pingping Chen, and Beverly Hudspeth for assistance.

Correspondence should be addressed to Greg M. Cole, Veterans Affairs, Greater Los Angeles Healthcare System Research 151, Building 7, Room A101, 16111 Plummer Street, North Hills, CA 91343. E-mail: gmcole@ucla.edu.

DOI:10.1523/JNEUROSCI.3593-07.2007

Copyright $\odot 2007$ Society for Neuroscience ～0270-6474/07/2714299-09\$15.00/0
(LR11), a member of the ApoE/low-density lipoprotein receptor family, was identified as a probable genetic risk factor for LOAD (Rogaeva et al., 2007). Polymorphisms associated with increased $\mathrm{AD}$ risk appeared to reduce LR11 mRNA in $\sim 15 \%$ of $\mathrm{AD}$ cases. Furthermore, neuronal LR11 expression is reduced in the overall LOAD population but not in FAD with the full spectrum of $A D$ pathology (Dodson et al., 2006). This argues that LR11 deficits in LOAD are not simply secondary to pathology and might play a causal role. LR11 functions as a sorting and trafficking protein, guiding APP into the recycling endosome pathways that lead to a reduction of $A \beta$ production (Offe et al., 2006).

Because lipoprotein receptor family proteins are frequently lipid-regulated, for example by cholesterol or essential fatty acids (Zheng et al., 2002), we reasoned that dietary lipids might increase LR11 expression to reduce AD risk. The only plasma lipid predictive of AD risk in the Framingham study was docosahexaenoic acid (DHA), an essential dietary n-3 ( $\omega-3)$ polyunsaturated fatty acid (PUFA) in which higher blood levels correlated with reduced AD assessed 10 years later (Johnson and Schaefer, 2006). Previous studies have found that dietary DHA significantly improved cognitive deficits, protected synaptic protein loss and lowered insoluble A $\beta$ in an aged DHA-depleted APPsw (Tg2576) transgenic $\mathrm{AD}$ mouse model, apparently by reducing $\mathrm{A} \beta$ produc- 
tion by an unknown mechanism (Calon et al., 2004; Lim et al., 2005). DHA mediated reductions in $A \beta$ have also been found in PS1 $\times$ APP mice (Oksman et al., 2006), $3 \times$ Tg mice (Green et al., 2007) and primary human neuronal cultures (Lukiw et al., 2005). Therefore, we hypothesized that DHA might increase LR11 levels which could contribute to the reduction of $A \beta$ observed in models and human neurons and risk for $\mathrm{AD}$ in epidemiological studies.

To test this hypothesis, we examined the effect of DHA on regulating LR1 1 in different systems in vitro and in vivo, including primary rat neurons, human neuronal SH-SY5Y cells, aged C57B6/SJL non-Tg mice, young rats in a model of insulin resistance and aged DHA-depleted Tg2576 mice fed with a safflower oil-enriched ("Bad") diet in which DHA supplementation had reduced A $\beta$ (Calon et al., 2004; Lim et al., 2005).

\section{Materials and Methods}

Cell culture and treatment

Cultured primary hippocampal and cortical neurons were prepared from embryonic $18 \mathrm{~d}$ Sprague Dawley rat fetuses as previously described (Zhao et al., 2004). Human SH-SY5Y neuroblastoma cells were maintained in DMEM supplemented with $2 \mathrm{~mm}$ L-glutamine and $10 \%(\mathrm{v} / \mathrm{v})$ fetal calf serum. Cells $\left(5 \times 10^{5}\right)$ were plated on six-well plates and grown to $80 \%$ confluence at $37^{\circ} \mathrm{C}$ in a humidified $5 \% \mathrm{CO}_{2}$ atmosphere incubator. Before adding DHA from stock 5 mm DHA (Cayman Chemical, Ann Arbor, MI) in $0.1 \%$ BSA in PBS, cells were incubated with Neurobasal without glutamate and B27 for primary neurons or DMEM media with $2 \%$ serum for SH-SY5Y cells for $24-72 \mathrm{~h}$ at $37^{\circ} \mathrm{C}$.

\section{Cell lysate preparation for Western blots}

Cultured cells were placed on ice, washed and scraped into cold PBS and $3000 \mathrm{rpm}$ microfuge pellets were dissolved in lysis buffer with protease and phosphatase inhibitors, sonicated, incubated $\left(4^{\circ} \mathrm{C}, 30 \mathrm{~min}\right)$, and centrifuged (14,000 rpm, $10 \mathrm{~min}$ ) (Zhao et al., 2004). Supernatants were used for Western blots.

\section{Animals and diets}

Animal protocols were approved by the Greater LA VA Institutional Animal Care and Use Committee. Three animal experiments used different animals and diets.

Experiment 1. Seventeen-month-old male and female C57B6/SJL non-Tg mice were randomly split into two treatment groups $(n=5 \sim 9)$. Mice were fed for $103 \pm 5 \mathrm{~d}$ with control diet (PMI 5015; PMI International LabDiet, St. Louis, MO), safflower oil-based diet depleted of n-3 PUFA ("Bad" diet, TD 96155; Harlan Teklad, Madison, WI) or the "Bad" diet to which $0.6 \%$ DHA (from algae; Martek, Columbia, MD) was added (Bad + DHA diet).

Experiment 2. Fructose-fed rats (FFRs; a model of insulin resistance, $n=5 \sim 6$; male 250-300 g CD:IGS rats) (Charles River Laboratories, Wilmington, MA) were divided into three diet groups for 7 weeks: (1) FFR diet group (60\% fructose by weight; Harlan Teklad), (2) FFR-fish oil group [FFR + fish oil (FO)] with FFR diet plus $1.1 \%$ containing $0.12 \%$ DHA and $0.18 \%$ eicosopentaenoic acid (EPA), or (3) FFR $+2.2 \%$ FO (0.24\% DHA and 0.36\% EPA) (Harlan Teklad).

Experiment 3. Seventeen-month-old male and female Tg2576 + mice were randomly split into 3 diet groups for $103 \pm 5 \mathrm{~d}(n=6 \sim 7)$ : a) control (PMI 5015; PMI International LabDiet, St. Louis, MO), b) safflower oil-based diet depleted of n-3 PUFA ("Bad" diet, TD 96155; Harlan Teklad) or c) Bad diet plus 0.6\% DHA (Bad + DHA) (Calon et al., 2004). Animals were perfused with $0.9 \%$ normal saline followed by HEPES buffer, $\mathrm{pH} 7$.2, containing protease inhibitors. Brain regions were dissected from one hemisphere as previously described (Lim et al., 2001). Unless otherwise noted, biochemical measurements were performed on the residual cortex (cortex region without frontal, entorhinal, or piriform areas) as previously reported (Calon et al., 2004).

\section{Tissue preparation}

TBS and lysis (membrane) soluble brain fractions containing protease and phosphatase inhibitors were prepared and detergent-insoluble pel- lets were extracted in $5 \mathrm{~m}$ guanidine as previously (Lim et al., 2001; Calon et al., 2004).

\section{Western blotting}

A total of $30 \mu \mathrm{g}$ of protein (Bio-Rad, Hercules, CA) lysis extracts were electrophoresed on 10-20\% Tris-tricine gradient gels, and Western blots (Lim et al., 2001) stained with anti-LR11 (1:1000; BD Biosciences, San Jose, CA) followed with goat anti-mouse secondary antibody at 1:10,000 for $1 \mathrm{~h}$ and developed using chemiluminescence reporting (Supersignal; Pierce, Rockford, IL). The BD Biosciences LR11 antibody used was originally developed by Transduction Laboratories (Lexington, KY) and used in all the figures in Rogaeva et al. (2007) to label LR11 including those showing LR11 transfected and siRNA treated cells (Dr. P. St. GeorgeHyslop, personal communication). Band intensities were scanned and quantified with densitometric software (Molecular Analyst II; Bio-Rad). For normalization, blots were re-probed with control neuron-specific enolase (NSE; Zymed Laboratories, South San Francisco, CA) or $\beta$-actin (Chemicon, Temecula, CA) antibodies.

\section{Immunocytochemical staining and image analysis}

Cortical neuron [7 d in vitro (DIV)] or $4 \mathrm{~d}$ SH-SY5Y poly-D-lysine-coated coverslip cultures were DHA or vehicle treated as described in legends. After treatment, cultures were PBS washed, 4\% paraformaldehyde fixed (10 min), blocked $30 \mathrm{~min}$. with $3 \%$ goat serum, $10 \%$ horse serum, $0.3 \%$ Triton X-100 in PBS and double labeled with anti-LR11 (1:100)/antimouse Rhodamine and anti-microtubule-associated protein 2 (MAP2) (1:500)/anti-rabbit FITC and mounted with 4-6-diamidino-2phenylindole (DAPI)-containing medium (Vector Laboratories, Burlingame, CA). Slides were viewed with a fluorescent microscope. Immunofluorescent LR11 staining density was quantified by digitally photographing with equal magnification and exposure time, a minimum of 100 neurons per treatment, and quantifying with automated analysis using 5 Image-Pro Plus Software to quantify the LR11 fluorescence levels.

\section{Real-time quantitative PCR}

A total of $2 \mu \mathrm{g}$ of total brain RNA isolated with TRI reagent (Molecular Research Center, Cincinnati, $\mathrm{OH}$ ) was reverse transcribed in triplicate with oligo-dT 15 primer (Promega, Madison, WI) using Ominiscript RT kits (Qiaqen, Valencia, CA) and Rnasin Ribonuclease Inhibitor (Promega) with other reagents and a 7300 instrument from Applied Biosystems (Branchurg, NJ). LR11 mRNA and internal standard (TaqMan Rodent GAPDH Control Reagent) levels were measured by quantitative PCR using TaqMan Master Mix and 7300 instrument standard thermocycling parameters. Dissociation curve analysis verified amplification of a single species. Standard curves typically had an $r^{2}>0.99$. Mouse LR11 primers were forward, TAGCCTGGGAAGCCCAGC; reverse, TGGCAGCTTCCAGAGGTACAC; FAM dye-labeled probe, CAGAGACATGCACAGTAAAAGCCCACGG. For rat LR11 primers were forward, GTCGGGACTGGTCTGATGAAG; reverse, GGAAGTTGGAGGCCTCACA and FAM dye-labeled probe, CAACTGCACCGCCATCTA.

\section{Statistical analysis}

Statistical analyses were performed with StatView 5.0 software. Differences among means were assessed by ANOVA followed by TukeyKramer post hoc test.

\section{Results \\ DHA increases LR11 protein levels in primary cortical neurons}

Because like APP, LR11 in brain is predominantly neuronal, to determine whether any dose of DHA could alter neuron LR11 levels relevant to $A \beta$ production, we first conducted doseresponse experiments in primary cortical neurons. 7 DIV primary cortical neurons were treated with $0.1 \%$ BSA vehicle alone or $0.1 \%$ BSA vehicle with $0.5,6.7$ and $12.5 \mu \mathrm{M}$ DHA for $48 \mathrm{~h}$, and LR11 protein levels were examined by immunostaining and immunoblotting. Figure $1 A$ shows that the most physiologically relevant low dose, $0.5 \mu \mathrm{M}$ DHA treatment, increased LR11 stain- 
A
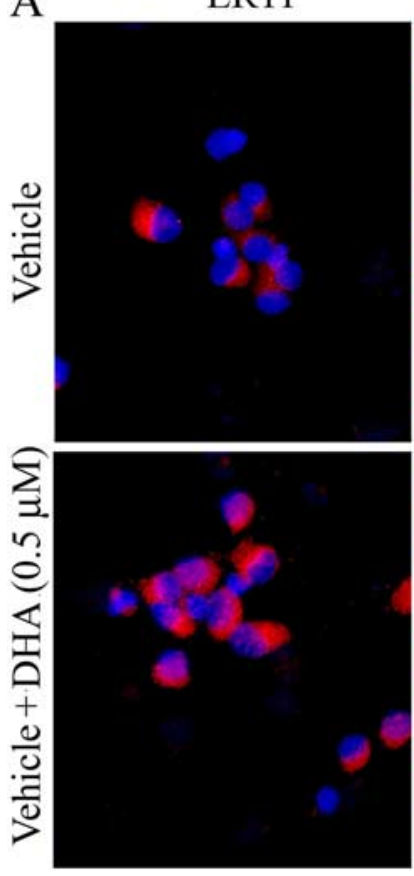

B
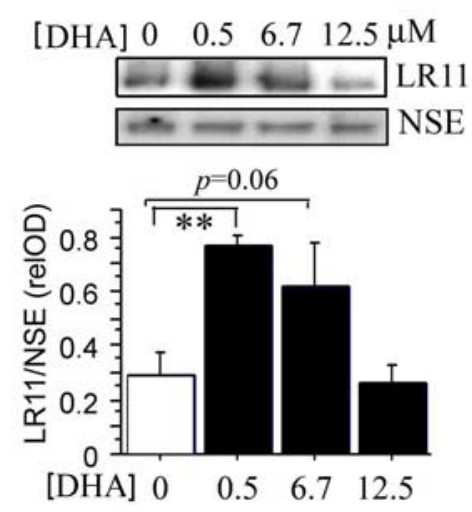

MAP2
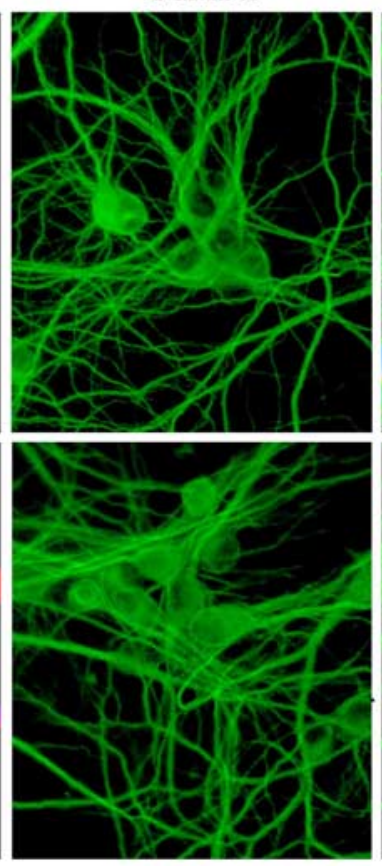

Merged
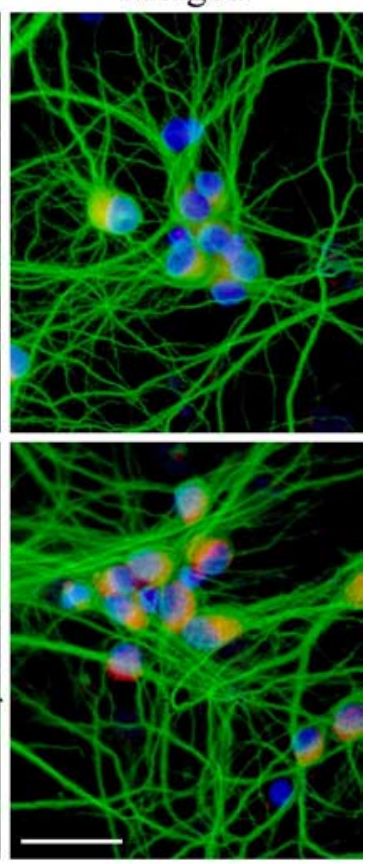

48 and $72 \mathrm{~h}, \mathrm{LR} 11$ protein levels were measured by Western blot and normalized using antibody to a neuron marker, NSE. The results indicated that DHA induced significant increases in LR11 protein levels at 48 and $72 \mathrm{~h}$ treatment when compared with vehicle $\left({ }^{*} p<0.05\right)$ (Fig. $1 C$ ), but not at $24 \mathrm{~h}$. All cultures used here were comprised of $\sim 95 \%$ pure neurons which was confirmed by immunostaining with a neuronspecific marker, MAP2 (Fig. $1 A$ ) and markers for contaminating glia (data not shown) which showed minimal labeling suggesting a likely direct effect on neurons.

\section{DHA increases LR11 protein levels in} human neural SH-SY5Y cell lines To confirm a direct impact of DHA on neuronal LR11 levels and show that this was not limited to rodent cells, we used human neuronal SH-SY5Y cells. LR11 immunostaining (red) was increased by treatment with $0.5 \mu \mathrm{M}$ DHA for $48 \mathrm{~h}$ when compared with $0.1 \%$ BSA vehicle alone. Quantification by image analysis of relative LR11 immunofluorescent intensity showed a significant increase in DHA treatment (7.379 \pm $0.258)$ compared with vehicle $(3.453 \pm$ $0.201)\left({ }^{* * *} p<0.001\right)$ (Fig. $\left.2 A\right)$. A DHA dose-response was also obtained with $\mathrm{SH}$ SY5Y cells (Fig. $2 \mathrm{~B}$ ). SY5Y cells were treated with $0.5,6.7$ and $12.5 \mu \mathrm{M}$ DHA for $48 \mathrm{~h}$, again, LR11 protein levels detected by Western blot were significantly increased by $0.5 \mu \mathrm{M}$ DHA treatment $\left({ }^{* *} p<0.01\right)$ when compared with vehicle alone. LR11 protein levels were normalized to NSE. These results are very similar to those obtained in primary cortical neurons. MAP2 as a neuron-specific marker was used to identify all human neuronal SY5Y in a field (Fig. $2 A$, green). $\mu \mathrm{M}$ DHA $+0.1 \% \mathrm{BSA})$ significantly increased LR11 levels in primary cortical neurons compared with vehicle alone $(0.1 \% \mathrm{BSA})$. Neurons were stained with anti-LR11 (red) and a neuronal marker, MAP2 (green) antibodies. Nuclei were labeled with DAPI (blue). Scale bar, $25 \mu \mathrm{m}$. B, Dose response of DHA-induced increases in LR11 protein levels. Cortical neurons were treated with 0.5, 6.7, and $12.5 \mu \mathrm{m}$ DHA for $48 \mathrm{~h}$, and LR11 levels were detected by Western blot. DHA significantly increased LR11 levels at a dose of $0.5 \mu \mathrm{M}\left({ }^{* *} p<0.01\right)$, with a strong trend at $6.7 \mu \mathrm{M}(p=0.06)$. C, Time course of DHA-induced increase in LR11. Cortical neurons were treated with $0.5 \mu \mathrm{M}$ DHA for 24,48 , and $72 \mathrm{~h}$, and LR11 protein levels were examined by Western blot. DHA significantly increased LR11 after 48 or $72 \mathrm{~h}$ treatment when compared with vehicle alone $\left({ }^{*} p<0.05\right)$. Error bars represent SEM; $n=3$ wells per treatment.

ing density in the primary neurons compared with vehicle neurons. Quantification by image analysis of relative LR11 immunofluorescent intensity showed a significant increase in DHA treatment $(27.420 \pm 0.070)$ compared with vehicle $(6.721 \pm$ $0.438)\left({ }^{* *} p<0.001\right)$. However, the effect was lost at DHA doses $>6.7 \mu \mathrm{M}$ (data not shown). These results were further confirmed by Western blot. Figure $1 B$ illustrates LR11 protein levels detected by immunoblotting were significantly increased in neurons treated with $0.5 \mu \mathrm{M} \mathrm{DHA}\left({ }^{* *} p<0.01\right)$ but only a trend toward an increase was obtained with $6.7 \mu \mathrm{M}$ DHA treatment $(p=0.06)$ when compared with vehicle alone. Using $0.5 \mu \mathrm{M}$ DHA, we then measured the time course for DHA-induced LR11 changes. Primary neurons were treated with $0.5 \mu \mathrm{M}$ DHA for 24,
DHA elevates LR11 protein levels in aged DHA-depleted C57B6/SJL mice

DHA plays a significant role in the developing brain so increases in cultured cells might reflect an impact on differentiation. However, our interest is in whether decreases in DHA in the brain could contribute to late-onset AD risk. Therefore, to ask whether DHA intake late in life can impact LR11 protein levels, we compared aged C57B6/SJL mice raised on an $\omega-3$ sufficient diet to $\sim 17$ months of age and then either placed on a DHA-depleting safflower oilenriched ("Bad") diet or the same diet enriched with DHA and kept until $\sim 22$ months of age when mice were killed and brains were examined. This DHA supplement regimen increases DHA content in frontal cortex compared with control breeder chow diet or DHA-depleting diet in aged mice (Calon et al., 2004). As hypothesized, the quantitative results from Western blot demonstrated that adding DHA significantly increased LR11 protein levels in these aged mice on DHA-depleting diet (3.834 \pm 1.252$)$ compared with the DHA-depleting diet alone $(0.928 \pm 0.246)$ 
$\left({ }^{* *} p<0.01\right)$ (Fig. 3A). LR11 protein levels were measured by Western blot and normalized by actin.

\section{DHA elevated LR11 levels in DHA- depleted aged $\mathrm{Tg} 2576$ mice}

Our previous studies reported that dietary DHA supplemented to a DHA-depleting (high safflower oil) diet protected from postsynaptic marker loss and improved cognitive deficits in aged DHA-depleted Tg2576 transgenic AD model mice (Calon et al., 2004). DHA supplements increased DHA and reduced $A \beta$ in brains of Tg2576 in which insoluble $A \beta 42$ by ELISA and amyloid plaque burden by ICC were both significantly reduced (Lim et al., 2005), but the molecular mechanisms underlying the $\mathrm{A} \beta$ effect were unknown. Here, we further investigated whether DHA diet in those experiments had significantly altered the LR11 levels in the aged APP Tg2576 mice. Compared with the standard $11 \%$ fat, $\omega$-3 sufficient 5015 P.M.I diet, Western blot analysis revealed a substantial decrease in LR11 levels in animals fed with the DHAdepleting "Bad" diet $\left({ }^{*} p<0.05\right)$ (Fig. 3B). This decrease was prevented when the "Bad" diet was supplemented with DHA $\left({ }^{*} p<0.05\right)$ (Fig. $3 B$ ), suggesting that DHA upregulation of LR11 expression also occurred in the Tg2576 AD mouse model. LR11 protein levels were normalized to actin. These data provide evidence that a DHA-enriched diet can significantly increase LR11 levels in the aged brain in vivo against the background of DHA depletion. This raised the questions of whether DHA could increase LR11 in vivo in models in the absence of a DHA-depleting diet and with younger animals and other species.

\section{Dietary fish oil increased LR11 protein levels in fructose-fed rats, an insulin-resistant diabetes animal model}

Because most of the epidemiological data relevant to DHA and $\mathrm{AD}$ risk concerns fish consumption and fish oil in the absence of FAD mutations, we sought to test the impact of fish oil in the absence of DHA-depletion in a nontransgenic model that incorporated another AD risk factor. Epidemiological studies indicate that insulin resistance with aging and type II diabetes mellitus are a significant risk factor for developing AD (Leibson et al., 1997; Ott et al., 1999). The enhanced risk for developing AD in diabetic patients may result from defects in insulin signaling that increase accumulation of pathological $\mathrm{A} \beta$ and/or hyperphosphorylated tau (Cole and Frautschy, 2007). DHA has been reported to have a protective effect against insulin resistance and alterations of insulin signaling in rodents in vivo (Delarue et al., 2004). Therefore, as a potential $\mathrm{AD}$-relevant model, we chose insulin-resistant rats on a high fructose corn syrup diet. Dietary fish oil has been reported to prevent oxidative stress in this model (Nyby et al., 2005). We observed that supplementation with $2.2 \%$ fish oil diet containing $0.24 \%$ DHA and $0.36 \%$ EPA for 8 weeks, significantly increased LR11 protein levels in 3- to 4-month-old insulin resis-
LR11

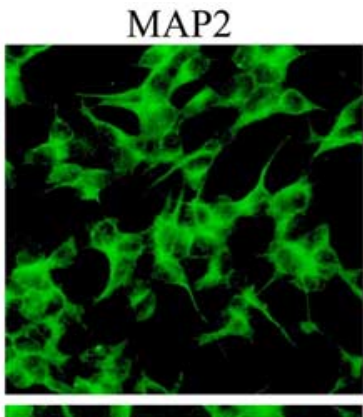

Merged
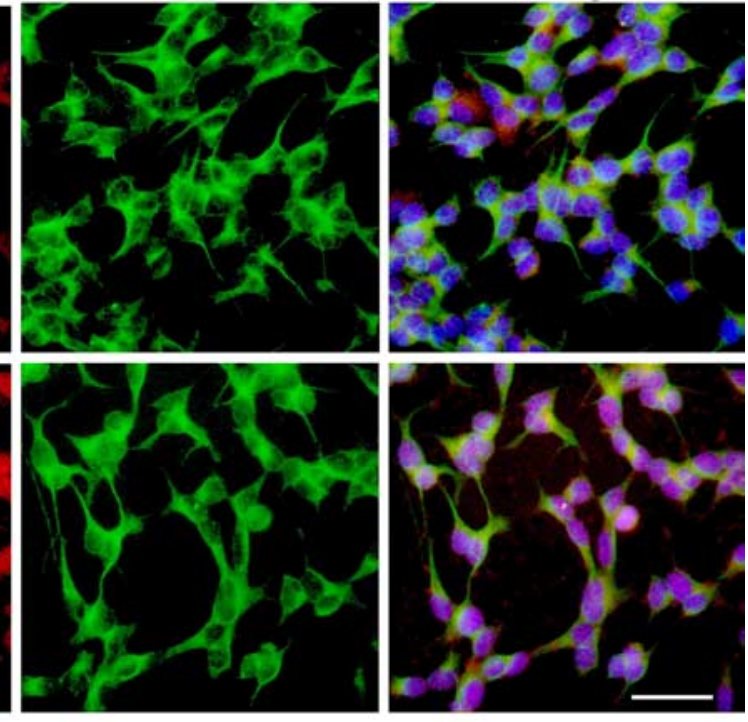

B

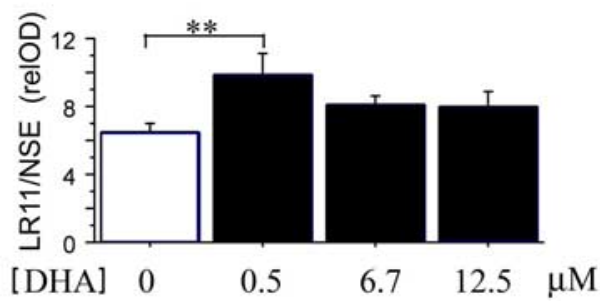

[DHA] $\quad 0 \quad 0.5 \quad 6.7 \quad 12.5 \quad \mu \mathrm{M}$

Figure 2. DHA increases LR11 protein levels in human neuronal SH-SY5Y cell lines. $A$, Immunostaining showed that DHA $(0.5$ treated with $0.5,6.7$, and $12.5 \mu \mathrm{m}$ DHA for $48 \mathrm{~h}$, and LR11 levels were detected by Western blot; DHA significantly increased LR11 at a dose of $0.5 \mu \mathrm{m}\left({ }^{* *} p<0.01\right)$. Error bars represent SEM; $n=3$ wells per treatment.

tant rats compared with the control fructose-fed group $\left({ }^{* *} p<\right.$ $0.01)$. Results were dose-dependent with an increase in $1.1 \%$ fish oil diet group $\left({ }^{*} p<0.05\right.$ ) (Fig. $3 C$ ). LR11 protein levels were again normalized by actin.

These data indicate that the effect on LR11 does not require DHA depleting conditions or occur only in aged mice and that like DHA derived from algae, the more common dietary supplement, fish oil, can increase LR11.

\section{DHA and fish oil increase LR11 mRNA expression but not in} all models

We used real-time PCR to quantify LR11/GAPDH mRNA levels in diet and cell culture studies (supplemental Table 1, available at www.jneurosci.org as supplemental material). DHA significantly increased LR11 mRNA in cultures of SH-SY5Y and primary rat cortical neurons, whereas fish oil showed a strong toward an increase in the insulin-resistant diabetes rat animal model. Also, the high safflower oil, DHA-depleting "Bad" diet significantly reduced LR11 mRNA in Tg2576-positive mice, and a similar trend toward lower message in the Tg-negative mice. However, DHA failed to restore LR11 mRNA in Tg2576-positive mice on "Bad" diet, arguing that increased LR11 mRNA cannot provide 
A B D B D B D B D B D

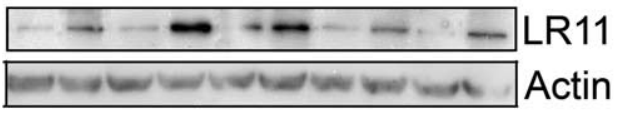

B
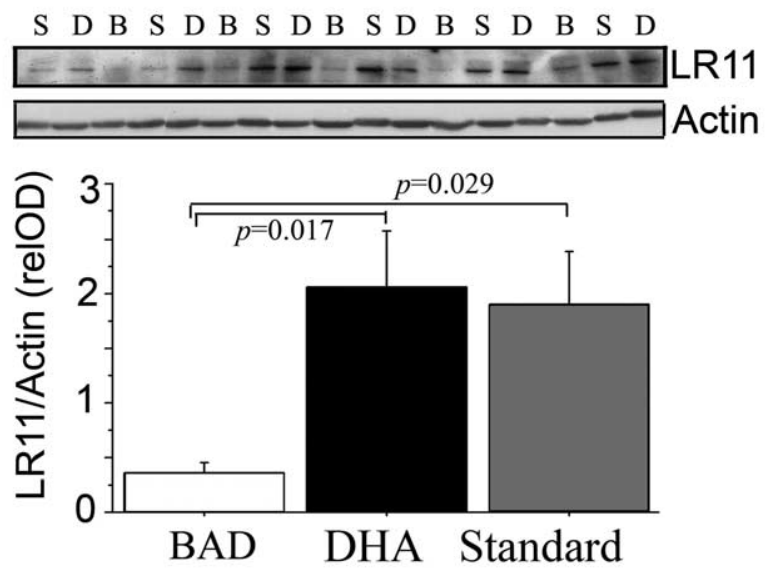

C

\% F.O. $0 \begin{array}{llllllllllllll} & 1.1 & 2.2 & 0 & 1.1 & 2.2 & 0 & 1.12 .2 & 0 & 1.12 .2 & 0 & 1.12 .2 & 2.2\end{array}$

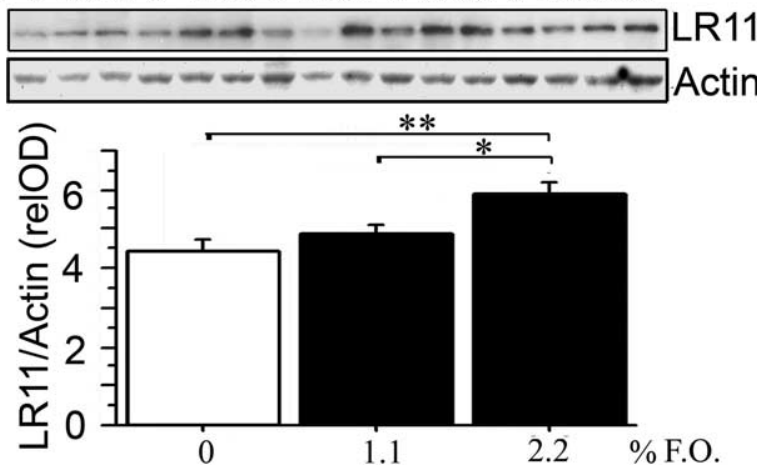

Figure 3. Impact of DHA or fish oil diets on cortical brain levels of $L R 11$ levels. $A$, Tg-negative mice at 22 months on DHA-depleting or DHA-supplemented diets. Quantification of LR11 levels were significantly elevated in the cortex of mice fed with DHA diet $(n=5 ; 3.834 \pm 1.252)$ compared with low n-3 PUFA diet alone, vehicles $(n=5 ; 0.928 \pm 0.246)(p<0.01)$. C57BL/SJL mice were fed PMI 5015, for 17 months, and then switched to DHA-depleting "Bad" diet (B) or DHA-supplemented "Bad" diets (D) until the animals were killed at 22 months. B, Tg2576 on DHA-depleted diet alone or supplemented with DHA. LR11 levels were significantly elevated in the cortex of Tg2576 mice fed DHA-supplemented "Bad" diet $(n=6)$ compared with Tg2576 mice fed DHA-depleting "Bad" diet alone from 17 to 22 months of age $(n=6, p<0.05)$. Bad diet-fed mice had significantly decreased LR11 levels compared with mice on standard PMI $5015 \operatorname{diet}(S)(n=6 ; p<0.05)$. C, Insulin-resistant rats supplemented with 1.1 or $2.2 \%$ fish oil (F.0.). LR11 levels were significantly increased in rats $(n=6)$ fed with $2.2 \%$ of fish oil compared with base diet $\left(n=5 ;{ }^{* *} p<0.01\right)$. A dose-dependent increase in LR11 was obtained with $1.1 \%$ fish oil $\left({ }^{*} p<0.05 ; n=5\right)$. Error bars represent SEM.

the only explanation for the protein increases and suggesting a possible impact on LR11 processing.

\section{DHA appeared to reduce soluble LR11}

Like the APP that it binds, LR11 itself is subject to proteolytic processing by an $\alpha$-secretase-like cleavage (by TACE) to release a large soluble extracellular product followed by processing of the C-terminal stub by $\gamma$-secretase (Bohm et al., 2006). Because mRNA changes in LR11 may have contributed to, but do not fully account for DHA-mediated increases in LR11 protein in the cellular fraction, we examined the possibility
A

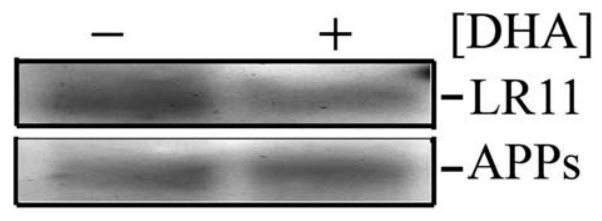

B
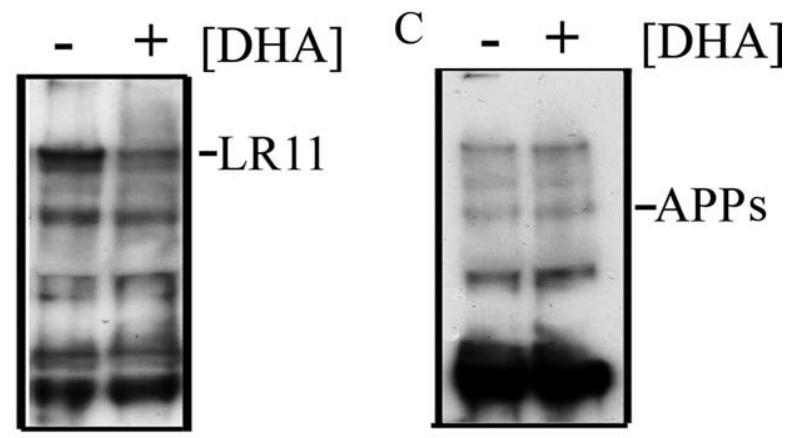

IP: LR11
WB: LR11

IP: 22C11

WB: 22C11

D

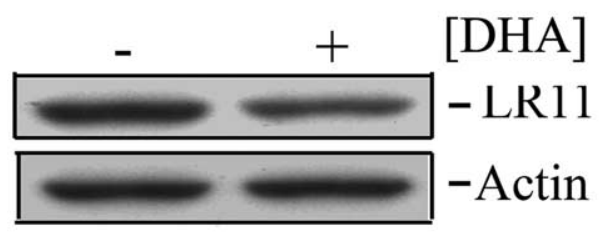

E

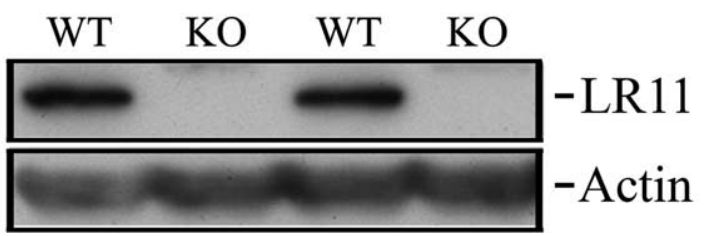

Figure 4. DHA reduces soluble LR11.A, Western blot for LR11 with densitometric analysis of $100 \mu \mathrm{l}$ samples of SH-SY5Y culture media from triplicate cultured cells treated as in Figure 1 shows reduced LR11 but not APPs with $48 \mathrm{~h}$ of $0.5 \mu \mathrm{m}$ DHA treatment $(0.590 \pm 0.126)$ compared with vehicle (1.983 \pm 0.302$)(p=0.0152)$. $\boldsymbol{B}$, Immunoprecipitation (IP) of media with LR11 followed by Western blot (WB) with the same antibody revealed both bands of an LR11 doublet reduced by LR11. C, Similar IP with anti-APP (22C11) followed by 22 C11 confirmed that there was no change in APPs with DHA. D, TBS-soluble LR11 showed a strong trend toward reduction in $\mathrm{Tg} 2576$ treated with DHA $(2.602 \pm 0.530)$ compared with vehicle $(4.595 \pm 0.864$; $p=0.0642$ ). $\boldsymbol{E}$, Wild-type (WT) versus LR11 knock-out (K0) mice confirms specificity of LR11 antibody used in these studies by showing complete loss of the $\sim 250 \mathrm{kDa}$ band in extracts from LR11 knock-out mice.

that DHA might reduce proteolytic release of LR11 into media in vitro or TBS soluble fractions in vivo. In the same cultures in which DHA significantly increased cell pellet SH-SY5Y LR11 protein (Fig. 2), DHA reduced soluble LR11 in media. Quantification analysis of relative LR11 band density from Western blot showed a significant decrease with DHA treatment $(0.590 \pm 0.126)$ compared with vehicle $(1.983 \pm 0.302)\left({ }^{*} p=\right.$ 0.0152 ) (Fig. 4A). Soluble APPs in the media did not significantly change and results were significant with or without normalization to APPs. When media was immunoprecipitated with anti-LR11 and blotted with the same antibody (Fig. $4 \mathrm{~B}$ ), an LR11 doublet $(\sim 250 \mathrm{kDa})$ was observed to be reduced by DHA consistent with reduced proteolytic LR11 cleavage and release. In contrast, IP with anti-APPs (22C11) and blotting 
with the same antibody (Fig. 4C) confirmed no change with DHA treatment. To determine whether or not DHA also influences LR11 processing in vivo, we examined the Tg2576 mice in which DHA treatment had left LR11 mRNA unchanged. DHA appeared to reduce TBS soluble LR11 but results did not reach statistical significance. Quantification analysis of relative LR11 band density from Western blot showed a trend to decrease with DHA treatment $(2.602 \pm 0.530)$ compared with vehicle $(4.595 \pm 0.864)(p=0.0642)($ Fig. $4 D)$.

Although the LR11 monoclonal antibody used in this study clearly detects LR11 as shown in Rogaeva et al. (2007), it is raised to a binding cluster domain and might also cross-react with other LDL receptors in brain. To rule this out, we tested the antibody on Western blots from wild type and LR11 knock-out mouse brain (the kind gift from Dr. T. Willnow, Berlin, Germany). The $\sim 250 \mathrm{kDa}$ LR 11 band quantified in our studies was entirely absent in LR11 knock-out mice confirming specificity (Fig. $4 E$ ).

\section{DHA did not affect ApoE mRNA or protein in DHA-depleted Tg2576 mice}

LR11 belongs to a member of the low density lipoprotein receptor (LDL-R) family reported to interact with ApoE (Jacobsen et al., 1996; Yamazaki et al., 1996). Because ApoE is a major component of brain lipoproteins, and ApoE genotype is a major susceptibility gene for LOAD, DHA effects on LR11 might alter $\mathrm{A} \beta$ deposition via an effect on ApoE. First, we compared the ApoE protein levels normalized by actin between non-Tg mice and Tg2576 mice by Western blot. Consistent with previous work (Terai et al., 2001), ApoE protein expression was significantly elevated in $\operatorname{Tg} 2576$ compared with the same background non-Tg mice $\left({ }^{*} p<0.05\right)$. However, DHA-enriched diet did not alter ApoE/GAPDH mRNA or protein expression in $\operatorname{Tg} 2576(p>0.05$, data not shown).

\section{LR11 mRNA or protein expression was not influenced by Tg2576 genotype}

Immunohistochemistry and immunoblotting of LR11 in middleaged PS1/APP transgenic and wild-type mice indicated that LR11 levels are not affected by mutant APP or PS1 or accumulation of amyloid pathology (Dodson et al., 2006). Consistent with this, we found that LR11 levels in both mRNA and protein expression were not different (data not shown, $p>0.05$ ) between non-Tg and Tg2576 mice. These data support the hypothesis that LR11 loss in LOAD is not secondary because it is not attributable to changes in APP or amyloid and not found in early-onset FAD (Dodson et al., 2006).

\section{Discussion}

The synergistic interaction of environmental and genetic factors likely contributes to the etiology of sporadic late-onset $\mathrm{AD}$. In this study, we demonstrated that a dietary fat, DHA, known to alter Alzheimer model pathogenesis (Calon et al., 2004; Lim et al., 2005) increases protein levels of a genetically implicated risk factor, LR11, a neuronal sorting protein that regulates APP processing to decrease $A \beta$ production. This observation may help explain epidemiology suggesting reduced $\mathrm{AD}$ risk associated with increased fish consumption and lower n-6/n-3 fatty acid ratios (Barberger-Gateau et al., 2002; Grant et al., 2002; Morris et al., 2003a,b; Kalmijn et al., 2004; Maclean et al., 2005).

We show DHA can regulate LR11 directly in different model systems in vitro and in vivo with and without DHA depletion and independently of age. Thus DHA can also increase LR11 in mem- brane fractions from young rat and normal aged mouse brain in the absence of DHA depletion or AD pathology, suggesting potential for disease prevention.

LR11 is mainly expressed in neurons (Jacobsen et al., 1996; Yamazaki et al., 1996; Motoi et al., 1999) and contains a vacuolar protein sorting 10 protein domain (vps10p), required for protein transport between the plasma membrane, endosomes and late Golgi compartments (Marcusson et al., 1994; Yamazaki et al., 1996; Jacobsen et al., 2002). Increased LR11 significantly alters the sorting and trafficking of APP to the recycling Golgi and early endosomal compartments which results in a decrease in $\mathrm{A} \beta$ production via the amyloidogenic pathway (Offe et al., 2006; Spoelgen et al., 2006). LR11 sorts APP to intracellular protein complexes (retromers) that traffic APP away from $\beta$ - and $\gamma$-secretase (Cam and $\mathrm{Bu}, 2006$ ). Retromer trafficking dysfunction, for example, with reduced LR11, can lead to increased APP in the late endosome, an organelle in which BACE activity and A $\beta$ production are maximized (Seaman, 2004; He et al., 2005). Confirming LR11's role in reducing A $\beta$, LR11 knock-out mice show increased brain $\mathrm{A} \beta$ (Andersen et al., 2005).

LR11 mRNA is downregulated in lymphoblasts and protein levels are reduced in brain and neurons from LOAD but not FAD patients (Scherzer et al., 2004; Dodson et al., 2006). Some decrease may be genetic as recent studies in diverse cohorts document multiple SORL1 polymorphisms that are significantly associated with risk for late-onset sporadic AD (Lee et al., 2007; Rogaeva et al., 2007). Consistent with observations of unchanged LR11 levels with increased APP or A $\beta$ in PS1/APP transgenics (Dodson et al., 2006), we found no alterations in aged Tg2576 APP transgenic mice with extensive plaque burden adding support to previous work arguing LR11 loss is not secondary to AD pathology. LOAD cases with no known genetic basis for LR11 loss may have LR11 deficits secondary to dietary risk factors, including DHA.

DHA treatment increased LR11 protein in membrane or whole cell pellet fractions while mRNA was increased, notably in human SY5Y and primary rat neurons, arguing for a primary transcription effect. The more limited effects in brain samples may be complicated by the selection of cortical regions from which RNA was prepared as well as the contribution from non-neuronal cells as LR11 expression has been reported in glial cells (Scherzer et al., 2004) and vascular smooth muscle cells (Ohwaki et al., 2007). DHA is highly enriched in neurons, so it may have little impact on the expression of LR11 in these other cell types. Suggesting an additional DHA effect on LR11 trafficking or metabolism, DHA treatment increased total LR11 in cultured SY5Y cell homogenates, but reduced soluble LR11 in media. A similar trend was observed in soluble fractions from Tg2576 in which mRNA was unchanged by DHA. DHA may influence LR11 trafficking by altering membrane fluidity and protein mobility or via its impact on signal transduction, for example on the phosphatidylinositol 3-kinase (PI3-K) pathway, which was reported to regulate LR11/retromer trafficking (Verges et al., 2007). Neuroprotective DHA treatment rescued p85 PI3-K in chronically treated Tg2576 (Calon et al., 2004). DHA is neuroprotective (Kishida et al., 1998; Kim et al., 2004; Hashimoto et al., 2005; Florent et al., 2006) but only after a preincubation period which allows the fatty acid time to be incorporated into cellular phospholipids and to increase phosphatidylsersine before increasing PI3-K pathway activity, notably Akt docking (Akbar et al., 2005). Alternatively, DHA may alter LR11 metabolism to reduce $\mathrm{A} \beta$ via the DHA metabolite, neuroprotectin D1, 
reportedly both neuroprotective and $\mathrm{A} \beta$ lowering (Lukiw et al., 2005).

Consistent with a delayed DHA effects on phospholipids or metabolites rather than a direct impact on putative DHAresponsive transcription factors LXR and RXR, we found no initial short-term LR11 response to DHA, but when primary cortical neurons or human neuronal SH-SY5Y cells were treated with DHA for $48 \mathrm{~h}$, we observed a robust and consistent increase in LR11. DHA mediated upregulation of LR11 was effective at 0.5 $\mu \mathrm{M}$, a dose which chronically reduced $\mathrm{A} \beta$ production by human neurons (Lukiw et al., 2005). This is in the range reported to protect cortical neurons or neuronal N2a cells from $\mathrm{A} \beta$ oligomer-induced apoptosis and to increase neuronal survival pathways (Florent et al., 2006). Higher doses used to protect rat hippocampal neurons from glutamate cytotoxicity $[15 \mu \mathrm{M}$ (Wang et al., 2003)] or human retinal pigment epithelial ARPE-19 cells exposed to oxidative stress [6.7 $\mu \mathrm{M}$ (Mukherjee et al., 2004)] may be less physiologically relevant. The reduced LR1 1 we observed at higher doses may reflect culture conditions, for example a failure to adequately protect high level DHA from oxidation, but no toxicity was observed. Given the high DHA in our animal studies with elevated LR11, it seems unlikely that the negative impact of very high DHA on LR11 will prove a similar problem in vivo, but future studies should address this possibility.

Results in animals have consistently shown that brain n-3 fatty acid content is highly dependent on dietary intake and aging (Favrelere et al., 2000; Youdim et al., 2000). DHA is reportedly reduced in AD (Soderberg et al., 1991; Praticò et al., 1998) which may be attributable to low dietary intake but also from losses from elevated lipid peroxidation in AD and Tg2576 mice (Pratico et al., 2001; Montine et al., 2004). Tg2576 mice (but not Tgnegative controls) fed a safflower oil-based, $\omega$-3 fatty aciddepleting diet showed a significant decrease of both brain DHA concentration and cognitive function (Calon et al., 2004). DHA supplementation significantly protected from synaptic protein loss, oxidative stress responses and cognitive deficits (Calon et al., 2004,2005 ) and reduced A $\beta$ (Lim et al., 2005). Along with published data showing LR11 decreases $A \beta$ production, our new findings suggest that DHA-induced increases in LR11 may contribute to observed reductions in $\mathrm{A} \beta$.

Although LR11 increases may have contributed to DHA effects on $\mathrm{A} \beta$, several other potential mechanisms for DHA's impact on $A \beta$ have been reported. For example in aged rats, fish oil can increase a brain $\mathrm{A} \beta$ transport protein, transthyretin (TTR), reportedly involved in A $\beta$ clearance(Puskas et al., 2003). DHA can also influence insulin signaling (Akbar et al., 2005) which in turn can regulate insulin degrading enzyme (IDE) which degrades A $\beta$ monomer (Zhao et al., 2004). However, in Tg2576, we have not been able to see a change in TTR or IDE (or BACE1) with dietary DHA (data not shown). But this does not rule out other effects in $\mathrm{AD}$ patients or models. In 3xTg-AD mouse models of $\mathrm{AD}$, dietary DHA suppressed soluble and intraneuronal $\mathrm{A} \beta$ and reduced $\gamma$-secretase component presenilin-1 (Green et al., 2007). Because DHA can impact multiple pathways capable of reducing $\mathrm{A} \beta$, a single pathway change may not reconcile all of the data. For example, increases in LR11 might reduce $\beta$-CTF, whereas DHA-induced reductions in $\gamma$-secretase could increase both $\alpha$ - and $\beta$-CTF. DHA treatment increased LR11 protein in membrane or whole cell pellet fractions while mRNA was increased, notably in human SY5Y and primary rat neurons, arguing for a primary transcription effect. Suggesting an additional DHA effect on LR11 trafficking or metabolism, DHA treatment increased total LR11 in cultured SY5Y cell homogenates but reduced soluble LR11 in media.

In summary, this study demonstrates that DHA can increase LR11, even in the absence of DHA depletion or AD pathology. Because genetic reduction of LR11 expression is associated with LOAD, dietary modulation of LR11 may influence risk. DHA-induced increase in LR11 provides one mechanism that may contribute to DHA-mediated reductions in $\mathrm{A} \beta$ with potential for $\mathrm{AD}$ prevention. Whether supplemental DHA can impact progression of established AD awaits evidence from a number of ongoing clinical trials in the US and Europe. Initial results from a 6 month fish oil trial delivering placebo or $1.7 \mathrm{~g} / \mathrm{d}$ DHA to mild to moderate AD patients found no impact on cognitive decline in the overall group, but apparent stabilization in patients at the earliest stages of cognitive decline (Freund-Levi et al., 2006). Our data and the clinical trial results suggest that DHA may be most useful for early intervention and prevention of late-onset AD.

\section{References}

Akbar M, Calderon F, Wen Z, Kim HY (2005) Docosahexaenoic acid: a positive modulator of Akt signaling in neuronal survival. Proc Natl Acad Sci USA 102:10858-10863.

Andersen OM, Reiche J, Schmidt V, Gotthardt M, Spoelgen R, Behlke J, von Arnim CA, Breiderhoff T, Jansen P, Wu X, Bales KR, Cappai R, Masters CL, Gliemann J, Mufson EJ, Hyman BT, Paul SM, Nykjaer A, Willnow TE (2005) Neuronal sorting protein-related receptor sorLA/LR11 regulates processing of the amyloid precursor protein. Proc Natl Acad Sci USA 102:13461-13466.

Bales KR, Verina T, Ghetti B, Dodel RC, Du Y, Altstie K, Bender M, Hyslop P, Johnstone EM, Little SP, Cummins DJ, Piccardo P, Paul SM (1997) Lack of apolipoprotein $\mathrm{E}$ dramatically reduces amyloid $\beta$-peptide deposition. Nat Genet 17:263-264.

Barberger-Gateau P, Letenneur L, Deschamps V, Peres K, Dartigues JF, Renaud S (2002) Fish, meat, and risk of dementia: cohort study. BMJ 325:932-933.

Bohm C, Seibel NM, Henkel B, Steiner H, Haass C, Hampe W (2006) SorLA signaling by regulated intramembrane proteolysis. J Biol Chem 281:14547-14553.

Calon F, Lim GP, Yang F, Morihara T, Teter B, Ubeda O, Rostaing P, Triller A, Salem Jr N, Ashe KH, Frautschy SA, Cole GM (2004) Docosahexaenoic acid protects from dendritic pathology in an Alzheimer's disease mouse model. Neuron 43:633-645.

Calon F, Lim GP, Morihara T, Yang F, Ubeda O, Salem Jr N, Frautschy SA, Cole GM (2005) Dietary n-3 polyunsaturated fatty acid depletion activates caspases and decreases NMDA receptors in the brain of a transgenic mouse model of Alzheimer's disease. Eur J Neurosci 22:617-626.

Cam JA, Bu G (2006) Modulation of beta-amyloid precursor protein trafficking and processing by the low density lipoprotein receptor family. Mol Neurodegener 1:8.

Cole GM, Frautschy SA (2007) The role of insulin and neurotrophic factor signaling in brain aging and Alzheimer's disease. Exp Gerontol 42:10-21.

Delarue J, LeFoll C, Corporeau C, Lucas D (2004) N-3 long chain polyunsaturated fatty acids: a nutritional tool to prevent insulin resistance associated to type 2 diabetes and obesity? Reprod Nutr Dev 44:289-299.

Dodson SE, Gearing M, Lippa CF, Montine TJ, Levey AI, Lah JJ (2006) LR11/SorLA expression is reduced in sporadic Alzheimer disease but not in familial Alzheimer disease. J Neuropathol Exp Neurol 65:866-872.

Favrelere S, Stadelmann-Ingrand S, Huguet F, De Javel D, Piriou A, Tallineau C, Durand G (2000) Age-related changes in ethanolamine glycerophospholipid fatty acid levels in rat frontal cortex and hippocampus. Neurobiol Aging 21:653-660.

Florent S, Malaplate-Armand C, Youssef I, Kriem B, Koziel V, Escanye MC, Fifre A, Sponne I, Leininger-Muller B, Olivier JL, Pillot T, Oster T (2006) Docosahexaenoic acid prevents neuronal apoptosis induced by soluble amyloid-beta oligomers. J Neurochem 96:385-395.

Freund-Levi Y, Eriksdotter-Jonhagen M, Cederholm T, Basun H, FaxenIrving G, Garlind A, Vedin I, Vessby B, Wahlund LO, Palmblad J (2006) 
Omega-3 fatty acid treatment in 174 patients with mild to moderate Alzheimer disease: OmegAD study: a randomized double-blind trial. Arch Neurol 63:1402-1408.

Goate A, Chartier-Harlin MC, Mullan M, Brown J, Crawford F, Fidani L, Giuffra L, Haynes A, Irving N, James L, Manti R, Newton P, Rooke K, Roques P, Talbot C, Pericak-Vance M, Roses A, Williamson R, Rossor M, Owen M, Hardy J (1991) Segregation of a missense mutation in the amyloid precursor protein gene with familial Alzheimer's disease. Nature 349:704-705.

Grant WB, Campbell A, Itzhaki RF, Savory J (2002) The significance of environmental factors in the etiology of Alzheimer's disease. J Alzheimers Dis 4:179-189.

Green KN, Martinez-Coria H, Khashwji H, Hall EB, Yurko-Mauro KA, Ellis L, LaFerla FM (2007) Dietary docosahexaenoic acid and docosapentaenoic acid ameliorate amyloid-beta and tau pathology via a mechanism involving presenilin 1 levels. J Neurosci 27:4385-4395.

Hashimoto M, Tanabe Y, Fujii Y, Kikuta T, Shibata H, Shido O (2005) Chronic administration of docosahexaenoic acid ameliorates the impairment of spatial cognition learning ability in amyloid beta-infused rats. J Nutr 135:549-555.

He X, Li F, Chang WP, Tang J (2005) GGA proteins mediate the recycling pathway of memapsin 2 (BACE). J Biol Chem 280:11696-11703.

Jacobsen L, Madsen P, Moestrup SK, Lund AH, Tommerup N, Nykjaer A, Sottrup-Jensen L, Gliemann J, Petersen CM (1996) Molecular characterization of a novel human hybrid-type receptor that binds the alpha2macroglobulin receptor-associated protein. J Biol Chem 271:31379-31383.

Jacobsen L, Madsen P, Nielsen MS, Geraerts WP, Gliemann J, Smit AB, Petersen CM (2002) The sorLA cytoplasmic domain interacts with GGA1 and -2 and defines minimum requirements for GGA binding. FEBS Lett 511:155-158.

Johnson EJ, Schaefer EJ (2006) Potential role of dietary n-3 fatty acids in the prevention of dementia and macular degeneration. Am J Clin Nutr 83:1494S-1498S.

Kalmijn S, van Boxtel MP, Ocke M, Verschuren WM, Kromhout D, Launer LJ (2004) Dietary intake of fatty acids and fish in relation to cognitive performance at middle age. Neurology 62:275-280.

Kim HY, Bigelow J, Kevala JH (2004) Substrate preference in phosphatidylserine biosynthesis for docosahexaenoic acid containing species. Biochemistry 43:1030-1036.

Kishida E, Yano M, Kasahara M, Masuzawa Y (1998) Distinctive inhibitory activity of docosahexaenoic acid against sphingosine-induced apoptosis. Biochim Biophys Acta 1391:401-408.

Lee JH, Cheng R, Schupf N, Manly J, Lantigua R, Stern Y, Rogaeva E, Wakutani Y, Farrer L, St George-Hyslop P, Mayeux R (2007) The association between genetic variants in SORL1 and Alzheimer disease in an urban, multiethnic, community-based cohort. Arch Neurol 64:501-506.

Leibson CL, Rocca WA, Hanson VA, Cha R, Kokmen E, O’Brien PC, Palumbo PJ (1997) The risk of dementia among persons with diabetes mellitus: a population-based cohort study. Ann NY Acad Sci 826:422-427.

Lim GP, Chu T, Yang F, Beech W, Frautschy SA, Cole GM (2001) The curry spice curcumin reduces oxidative damage and amyloid pathology in an Alzheimer transgenic mouse. J Neurosci 21:8370-8377.

Lim GP, Calon F, Morihara T, Yang F, Teter B, Ubeda O, Salem Jr N, Frautschy SA, Cole GM (2005) A diet enriched with the omega-3 fatty acid docosahexaenoic acid reduces amyloid burden in an aged Alzheimer mouse model. J Neurosci 25:3032-3040.

Lukiw WJ, Cui JG, Marcheselli VL, Bodker M, Botkjaer A, Gotlinger K, Serhan CN, Bazan NG (2005) A role for docosahexaenoic acid-derived neuroprotectin D1 in neural cell survival and Alzheimer disease. J Clin Invest 115:2774-2783.

Maclean CH, Issa AM, Newberry SJ, Mojica WA, Morton SC, Garland RH, Hilton LG, Traina SB, Shekelle PG (2005) Effects of omega-3 fatty acids on cognitive function with aging, dementia, and neurological diseases. Evid Rep Technol Assess (Summ) 1-3.

Marcusson EG, Horazdovsky BF, Cereghino JL, Gharakhanian E, Emr SD (1994) The sorting receptor for yeast vacuolar carboxypeptidase $Y$ is encoded by the VPS10 gene. Cell 77:579-586.

Montine KS, Quinn JF, Zhang J, Fessel JP, Roberts II LJ, Morrow JD, Montine TJ (2004) Isoprostanes and related products of lipid peroxidation in neurodegenerative diseases. Chem Phys Lipids 128:117-124.

Morris MC, Evans DA, Bienias JL, Tangney CC, Bennett DA, Aggarwal N,
Schneider J, Wilson RS (2003a) Dietary fats and the risk of incident Alzheimer disease. Arch Neurol 60:194-200.

Morris MC, Evans DA, Bienias JL, Tangney CC, Bennett DA, Wilson RS, Aggarwal N, Schneider J (2003b) Consumption of fish and n-3 fatty acids and risk of incident Alzheimer disease. Arch Neurol 60:940-946.

Motoi Y, Aizawa T, Haga S, Nakamura S, Namba Y, Ikeda K (1999) Neuronal localization of a novel mosaic apolipoprotein E receptor, LR11, in rat and human brain. Brain Res 833:209-215.

Mukherjee PK, Marcheselli VL, Serhan CN, Bazan NG (2004) Neuroprotectin D1: a docosahexaenoic acid-derived docosatriene protects human retinal pigment epithelial cells from oxidative stress. Proc Natl Acad Sci USA 101:8491-8496.

Nyby MD, Matsumoto K, Yamamoto K, Abedi K, Eslami P, Hernandez G, Smutko V, Berger ME, Tuck ML (2005) Dietary fish oil prevents vascular dysfunction and oxidative stress in hyperinsulinemic rats. Am J Hypertens 18:213-219.

Offe K, Dodson SE, Shoemaker JT, Fritz JJ, Gearing M, Levey AI, Lah JJ (2006) The lipoprotein receptor LR11 regulates amyloid beta production and amyloid precursor protein traffic in endosomal compartments. J Neurosci 26:1596-1603.

Ohwaki K, Bujo H, Jiang M, Yamazaki H, Schneider WJ, Saito Y (2007) A secreted soluble form of LR11, specifically expressed in intimal smooth muscle cells, accelerates formation of lipid-laden macrophages. Arterioscler Thromb Vasc Biol 27:1050-1056.

Oksman M, Iivonen H, Hogyes E, Amtul Z, Penke B, Leenders I, Broersen L, Lutjohann D, Hartmann T, Tanila H (2006) Impact of different saturated fatty acid, polyunsaturated fatty acid and cholesterol containing diets on beta-amyloid accumulation in APP/PS1 transgenic mice. Neurobiol Dis 23:563-572.

Ott A, Stolk RP, van Harskamp F, Pols HA, Hofman A, Breteler MM (1999) Diabetes mellitus and the risk of dementia: The Rotterdam Study. Neurology 53:1937-1942.

Pedersen NL, Gatz M, Berg S, Johansson B (2004) How heritable is Alzheimer's disease late in life? Findings from Swedish twins. Ann Neurol 55:180-185.

Praticò D, Lee VM-Y, Trojanowski JQ, Rokach J, Fitzgerald GA (1998) Increased F2-isoprostanes in Alzheimer's disease: evidence for enhanced lipid peroxidation in vivo. FASEB J 12:1777-1783.

Pratico D, Uryu K, Leight S, Trojanoswki JQ, Lee VM (2001) Increased lipid peroxidation precedes amyloid plaque formation in an animal model of Alzheimer amyloidosis. J Neurosci 21:4183-4187.

Puskas LG, Kitajka K, Nyakas C, Barcelo-Coblijn G, Farkas T (2003) Shortterm administration of omega 3 fatty acids from fish oil results in increased transthyretin transcription in old rat hippocampus. Proc Natl Acad Sci USA 100:1580-1585.

Rogaev EI, Sherrington R, Rogaeva EA, Levesque G, Ikeda M, Liang Y, Chi H, Lin C, Holman K, Tsuda T, Mar L, Sorbi S, Nacmias B, Piacentini S, Amaducci L, Chumakov I, Cohen D, Lannfelt L, Fraser PE, Rommens JM, et al. (1995) Familial Alzheimer's disease in kindreds with missense mutations in a gene on chromosome 1 related to the Alzheimer's disease type 3 gene. Nature 376:775-778.

Rogaeva E, Meng Y, Lee JH, Gu Y, Kawarai T, Zou F, Katayama T, Baldwin CT, Cheng R, Hasegawa H, Chen F, Shibata N, Lunetta KL, PardossiPiquard R, Bohm C, Wakutani Y, Cupples LA, Cuenco KT, Green RC, Pinessi L, et al. (2007) The neuronal sortilin-related receptor SORL1 is genetically associated with Alzheimer disease. Nat Genet 39:168-177.

Saunders AM, Strittmatter WJ, Schmechel D, George-Hyslop PH, PericakVance MA, Joo SH, Rosi BL, Gusella JF, Crapper-MacLachlan DR, Alberts MJ, Hulette C, Grain B, Goldgaber D, Roses AD (1993) Association of apolipoprotein $\mathrm{E}$ allele epsilon 4 with late-onset familial and sporadic Alzheimer's disease. Neurology 43:1467-1472.

Scherzer CR, Offe K, Gearing M, Rees HD, Fang G, Heilman CJ, Schaller C, Bujo H, Levey AI, Lah JJ (2004) Loss of apolipoprotein E receptor LR11 in Alzheimer disease. Arch Neurol 61:1200-1205.

Seaman MN (2004) Cargo-selective endosomal sorting for retrieval to the Golgi requires retromer. J Cell Biol 165:111-122.

Sherrington R, Rogaev EI, Liang Y, Rogaeva EA, Levesque G, Ikeda M, Chi H, Lin C, Li G, Holman K, Tsuda T, Mar L, St. George-Hyslop PH (1995) Cloning of a gene bearing missense mutations in early-onset familial Alzheimer's disease. Nature 375:754-760.

Soderberg M, Edlund C, Kristensson K, Dallner G (1991) Fatty acid com- 
position of brain phospholipids in aging and in Alzheimer's disease. Lipids 26:421-425.

Spoelgen R, von Arnim CA, Thomas AV, Peltan ID, Koker M, Deng A, Irizarry MC, Andersen OM, Willnow TE, Hyman BT (2006) Interaction of the cytosolic domains of sorLA/LR11 with the amyloid precursor protein (APP) and $\beta$-secretase $\beta$-site APP-cleaving enzyme. J Neurosci 26:418-428.

Terai K, Iwai A, Kawabata S, Sasamata M, Miyata K, Yamaguchi T (2001) Apolipoprotein E deposition and astrogliosis are associated with maturation of beta-amyloid plaques in betaAPPswe transgenic mouse: implications for the pathogenesis of Alzheimer's disease. Brain Res 900:48-56.

Verges M, Sebastian I, Mostov KE (2007) Phosphoinositide 3-kinase regulates the role of retromer in transcytosis of the polymeric immunoglobulin receptor. Exp Cell Res 313:707-718.

Wang X, Zhao X, Mao ZY, Wang XM, Liu ZL (2003) Neuroprotective effect of docosahexaenoic acid on glutamate-induced cytotoxicity in rat hippocampal cultures. NeuroReport 14:2457-2461.
Yamazaki H, Bujo H, Kusunoki J, Seimiya K, Kanaki T, Morisaki N, Schneider WJ, Saito Y (1996) Elements of neural adhesion molecules and a yeast vacuolar protein sorting receptor are present in a novel mammalian low density lipoprotein receptor family member. J Biol Chem 271:24761-24768.

Youdim KA, Martin A, Joseph JA (2000) Essential fatty acids and the brain: possible health implications. Int J Dev Neurosci 18:383-399.

Zhao L, Teter B, Morihara T, Lim GP, Ambegaokar SS, Ubeda OJ, Frautschy SA, Cole GM (2004) Insulin-degrading enzyme as a downstream target of insulin receptor signaling cascade: implications for Alzheimer's disease intervention. J Neurosci 24:11120-11126.

Zheng X, Rivabene R, Cavallari C, Napolitano M, Avella M, Bravo E, Botham KM (2002) The effects of chylomicron remnants enriched in $n-3$ or $n-6$ polyunsaturated fatty acids on the transcription of genes regulating their uptake and metabolism by the liver: influence of cellular oxidative state. Free Radic Biol Med 32:1123-1131. 